\title{
Satellite Glial Cells and Astrocytes, a Comparative Review
}

DOI:

$10.1007 / \mathrm{s} 11064-021-03255-8$

\section{Document Version}

Accepted author manuscript

Link to publication record in Manchester Research Explorer

\section{Citation for published version (APA):}

Hanani, M., \& Verkhratsky, A. (2021). Satellite Glial Cells and Astrocytes, a Comparative Review. Neurochemical research. https://doi.org/10.1007/s11064-021-03255-8

\section{Published in:}

Neurochemical research

\section{Citing this paper}

Please note that where the full-text provided on Manchester Research Explorer is the Author Accepted Manuscript or Proof version this may differ from the final Published version. If citing, it is advised that you check and use the publisher's definitive version.

\section{General rights}

Copyright and moral rights for the publications made accessible in the Research Explorer are retained by the authors and/or other copyright owners and it is a condition of accessing publications that users recognise and abide by the legal requirements associated with these rights.

\section{Takedown policy}

If you believe that this document breaches copyright please refer to the University of Manchester's Takedown Procedures [http://man.ac.uk/04Y6Bo] or contact uml.scholarlycommunications@manchester.ac.uk providing relevant details, so we can investigate your claim.

\section{OPEN ACCESS}




\section{Satellite glial cells and astrocytes, a comparative review}

By Menachem Hanani ${ }^{1}$ \& Alexei Verkhratsky $y^{2,3}$

${ }^{1}$ Laboratory of Experimental Surgery. Hadassah-Hebrew University Medical Center and Faculty of Medicine, the Hebrew University of Jerusalem, Israel

${ }^{2}$ Faculty of Biology, Medicine and Health, The University of Manchester, Manchester, M13 9PT, UK

${ }^{3}$ Achucarro Center for Neuroscience, IKERBASQUE, 48011, Bilbao, Spain

\section{Acknowledgments}

We thank Prof. Amin Derouiche (University of Frankfurt) for helpful suggestions. MH was supported by the Israel Science Foundation (1297/18) and by the United States-Israel Binational Science Foundation (BSF, 2019076).

Send all correspondence to:

Prof. Menachem Hanani, The Hebrew University of Jerusalem, Israel

Email: hananim@mail.huji.ac.il

ORCID 0000-0002-6716-1453 


\begin{abstract}
Astroglia are neural cells, heterogeneous in form and function, which act as supportive elements of the central nervous system; astrocytes contribute to all aspects of neural functions in health and disease. Through their highly ramified processes, astrocytes form close physical contacts with synapses and blood vessels, and are integrated into functional syncytia by gap junctions. Astrocytes interact among themselves and with other cells types (e.g., neurons, microglia, blood vessel cells) by an elaborate repertoire of chemical messengers and receptors; astrocytes also influence neural plasticity and synaptic transmission through maintaining homeostasis of neurotransmitters, $\mathrm{K}^{+}$buffering, synaptic isolation and control over synaptogenesis and synaptic elimination. Satellite glial cells (SGCs) are the most abundant glial cells in sensory ganglia, and are believed to play major roles in sensory functions, but so far research into SGCs attracted relatively little attention. In this review we compare SGCs to astrocytes with the purpose of using the vast knowledge on astrocytes to explore new aspects of SGCs. We survey the main properties of these two cells types and highlight similarities and differences between them. We conclude that despite the much greater diversity in morphology and signaling mechanisms of astrocytes, there are some parallels between them and SGCs. Both types serve as boundary cells, separating different compartments in the nervous system, but much more needs to be learned on this aspect of SGCs. Astrocytes and SGCs employ chemical messengers and calcium waves for intercellular signaling, but their significance is still poorly understood for both cell types. Both types undergo major changes under pathological conditions, which have a protective function, but an also contribute to disease, and chronic pain in particular. The knowledge obtained on astrocytes is likely to benefit future research on SGCs.
\end{abstract}

Key words: neuroglia; satellite glial cell, astrocyte, sensory ganglia, receptors, transporters 


\section{Introduction}

Glial cells populate both peripheral and central nervous systems (PNS and CNS respectively; Fig. 1, [1]). Except for myeloid microglia, all neuroglial cells are of ectodermal origin, with the CNS macroglia developing from neuroepithelium and radial glia, whereas PNS glia being scions of the neural crest cells [2-4]. Fundamentally, CNS and PNS glia are supportive cells, responsible for maintenance of neuronal networks. Myelinating cells, represented by Schwann cells in the PNS and oligodendrocytes in the CNS are indispensable for myelination and for axonal support [5]. Homeostatic glia, which includes astrocytes in the CNS and satellite glial cells (SGCs), olfactory ensheathing cells and enteric glia in the PNS, control nervous system homeostasis on all levels of organization from molecular to organ $[1,6]$. Satellite glial cells, which are the main type of homoestatic glial cells in PNS ganglia (sensory, parasympathetic and sympathetic, but not in the enteric nervous system), seem to be functionally similar to astrocytes. Astrocytes have been researched in great detail; our knowledge about SGCs is much less advanced, and yet certain similarities between these cell types can be noted [7]. This review is an attempt to examine SGCs by comparing them with astrocytes. The comparative approach has a long history in biology, especially in the context of observational studies [8], and it has merits for any field in biomedicine. Astrocytes have been the topic of intense research for many decades, and therefore comparing them to the much less studied SGCs is likely to benefit SGC research. Such approach may lead to new ideas on how to interpret available data on SGCs and what research questions can be asked about them.

When discussing astrocytes, we must keep in mind their great diversity; it is impossible to regard and describe them as a single entity. Nonetheless, all astroglial cells have certain common features and hence some idealized archetypal astrocyte can be devised. Another caveat is that comparing a cell type that is well-characterized to one that is known to a much lesser extent may not be well-balanced. In many areas there is little or nothing to say about SGCs, and we will, therefore, limit the discussion to aspects of astrocytes that are potentially relevant to SGCs. The goal of this review is to use the knowledge of astrocytes to advance the understating SGCs to and plot the future progress in research on them. 


\section{Comparative anatomy of astrocytes and satellite glia}

Since the early days of neuroscience, neuroanatomy paved the way to understanding the function of the nervous system. Camillo Golgi, who stained astrocytes with "reazione nero" discovered their vascular endfeet, and based on this observation, the concept of astrocyte as an interface between the brain parenchyma and vasculature has been born [9]. Santiago Ramon-y-Cajal, when observing neurons and axo-denritic contacts contemplated that "only impulses of the same direction can travel through its appendages" and thus formulated the law of dynamic polarization in neuronal networks [10]. Carl Ludwig Schleich, by observing intimate relations between neurons and neuroglia suggested that glial cells control synaptic transmission [11]. To continue with this trend we shall start our narrative from analyzing and comparing anatomical features of SGCs and astrocytes (Table 1).

\subsection{Cellular processes and contacts}

The CNS contains many types of astrocytes (see Fig. 1) with distinct morphology and function, including protoplasmic astrocytes of grey matter, fibrous astrocytes of grey matter, velate astrocytes of supraoptic nucleus and cerebellum, radial astrocytes (cerebellar Bergmann glia, retinal Müller glia, hypothalamic tanycytes and stem astrocytes of the neurogenic niches), numerous specialized astrocytes and ependymal cells of choroids plexus [6]. It is generally believed that astroglial morphology and function is closely regulated by their immediate environment. In contrast, hitherto no evidence for SGC heterogeneity or existence of several SGCs subtypes is available neither within an individual ganglion, nor between different ganglia. Some differences have been noted between neurons in dorsal root (DRG) and trigeminal ganglia [12], and it could be assumed that SGCs in these ganglia may display some unique features. This however, remains a speculation and the available information indicates that SGCs in different sensory ganglia are quite similar, although this has not been studied systematically. It is possible that transcriptomic analysis [13] may reveal heterogeneities between different ganglia and stimulate a focused search for SGC subtypes. 
Here we shall describe the anatomy of the most common type of astroglial cell in cerebral grey matter, the protoplasmic astrocyte [6]. Protoplasmic astrocytes are characterized by extensive arborization, which defines the territorial domain of an individual cell [14], these territorial domains divide the cortical grey matter into relatively independent neuro(glio)-vascular units [15]. Protoplasmic astrocytes have a relatively small cell body from which several $(4-10$ in rodents and up to 50 in humans) primary processes emanate. These primary processes give rise to numerous finer distal processes. Primary processes are generally known as branches and branchlets, whereas distal processes are defined as leaflets, which are $100-150 \mathrm{~nm}$ thick and do not possess intracellular organelles [16, 17]. Astrocytic leaflets contribute to the formation of the neuropil and contact synapses $(\sim 60-70 \%$ of grey matter synapses, depending on the region, have astroglial coverage). The key morphological feature of leaflets is a high surface to volume ratio, which allows dense concentration of homeostatic solute carrier transporters in the vicinity of synapses [18-20]. Astroglial support is fundamental for synaptic connectivity, because astrocytes control all aspects of synaptic existence from synaptogenesis to synaptic isolation, maintenance and extinction; these multiple roles have been formalized in the concept of astroglial cradle [21, 22]. Distal astrocytic processes also establish gap junctional contacts with neighboring astrocytes, thus creating anatomically segregated astroglial syncytia [23-25]. Astroglial gap junctions are assembled from connexins (Cx) 43, 30 and $26[26,27]$. Of these, Cx43 is the most abundant and is often used as astrocyte-specific marker [28]. Gap junctions provide intercellular diffusional pathways for ions and molecules with molecular weight below $1000 \mathrm{Da}$, including second messengers and metabolites $[29,30]$.

In addition to branches and distal leaflets, protoplasmic astrocytes project at least one process towards nearby blood vessel; walls of all parenchymal vessels are plastered by astrocytic endfeet, which create glia limitans vascularis [31]. At the surface of the brain astroglial endfeet form glia limitans externa separating the brain from the pia mater. In some regions of the brain (for example in piriform cortex) the glia limitans externa is formed by specialized surface-associated astrocytes [32]. Conceptually, glial endfeet represent the parenchymal portion of the blood-brain and bloodcerebrospinal fluid barriers [33]. Moreover, endfeet contribute to the regulation of local blood flow through secreting vasoconstricting and vasodilatating factors [34-36]. 
In contrast to astrocytes, SGCs have a much simpler morphology; as a rule, single SCG contacts a single neuron, although in some cases an SGC may contact two neurons $[37,38]$. SGCs are flat, they enwrap neurons and contain a small amount of cytoplasm thus (similarly to astroglial leaflet processes) they have high surface to volume ratio. It is logical to assume that the SGC envelope can serve as a partial protective layer for the neurons, at least in slowing down the access of molecules and cells to the neurons. The SGCs barrier between neighboring neurons is, however, not very tight, being permeable to proteins and macrophages [39, 40]. Currently the question of whether the SGC envelope can function as a partial barrier is still open. This matter is relevant because the ganglia do not possess a dedicated barrier with circulation, and in the absence of the SGCs, neurons may be exposed to blood-borne substances. Although there are many blood vessels in sensory ganglia [41], there is currently no evidence for any specialized contacts between SGCs and these vessels. This however, does not exclude the possibility that SGCs may contribute to the local control of blood flow.

The most distinctive morphological feature of SGCs is that their somata and processes surround the neurons completely. Such an arrangement is not found in the CNS, although some authors have employed the term "satellite glia" for CNS glia and defined certain form of gliotic response as "satellitosis"; in all cases the cells in question were of oligodendroglial lineage $[42,43]$, and their functional role remains unclear. Astroglial processes enwrap synapses and neuronal cell bodies [6], and therefore SGCs and astrocytes are conceptually similar. There are, however, no examples of the CNS glial cells which wrap around neurons their entirety. Neuronastrocyte contacts are highly diverse and vary between brain regions from complete ensheathment of certain neurons (for example velate astrocytes) and synapses to complete absence of astrocytes in neuropil compartments. For example, astrocytes are absent in the sensory synaptic neuropil compartment in olfactory glomeruli and around certain types of synapses [44]. Nonetheless, fundamentally astrocytes and SGCs serve as boundary cells, separating distinct compartments, although the barrier role of SGCs needs to be explored in detail. Both cells types separate and shield neurons from blood vessels and perineuronal spaces. Astrocytes establish the glia limitans in the CNS, whereas SGCs ensheathe ganglionic neurons and have their own 
basal lamina [38], the whole structure therefore can be regarded as a "ganglionic glia limitans".

\subsection{Cellular polarization}

As outlined above, astrocytes are highly polarized cells; whether SGCs share this property remains to be seen. The SGCs have flat processes, and because there are no synapses in sensory ganglia, perisynaptic contacts are absent. It is reasonable to assume that the flat SGC processes are symmetric in the direction parallel to the neuronal surface. However, in the radial direction, i.e. perpendicular to the SGC surface, polarization may occur. Because SGCs separate neurons from the space occupied by connective tissue, they may be organized similarly to epithelial cells that are highly polarized. Such property would bestow on SGCs the ability to control various types of passage of ions and molecules across them. For example, if amino acid transporters are concentrated on the cell surface facing the neurons, it may allow SGCs to accumulate and move these amino acids away from the neurons. This however remains a speculation. Ultrastructural analysis provided some evidence that the outer surface of the SGC sheath is generally smoother than that facing the neuron, which increases the area of contact with the neuronal side [38]. A single observation that SGC side facing the neuron is enriched with actin, supports the notion of polarity in the radial direction [45]. This observation is, however, in conflict with previous report showing that actin is localized preferably in neurons and is rather scarce in SGCs [46]. This matter warrants further study, in connection with the general question of SGC polarity.

\subsection{Domain organization}

Protoplasmic astrocytes occupy individual territorial domains with little (less than $5 \%$ ) overlap between their distal processes [14]. Within these domains an individual astrocyte establishes contacts with $\sim 20000-10000$ synapses in rodents and with up to 2 million synapses in humans [14, 47-49].The neuron-SGC unit, is completely different. In most cases a given neuron is covered with its dedicated SGCs. On rare occasions two to three neurons are surrounded by a common SGC sheath - an arrangement known as "cluster" $[38,50]$. The number of SGCs surrounding each 
neuron is proportional to neuronal size, with 10 to 20 SGCs per neuron in large mammals. On average, the ratio between SCGs and neurons is 3.8:1 in gecko, 5.5:1 in mouse, 8.2:1 in rat, and 10.2:1 in rabbit [51]. The SGC processes are flat and intermingle with those of other SGCs that envelope the neuron. Close interactions with the neuron are very likely, because of the narrow (about $20 \mathrm{~nm}$ ) gap between the two cell types. Neurons send numerous fine processes, similar to microvilli, into the SGCs cover. These processes appear throughout the neuronal surface, thus greatly increasing neuronal surface and the contact area with SGCs [38, 52]. Currently, information on SGC-neuronal reciprocal interactions is scarce, and yet these interactions are likely to be present and to play major roles in the function of peripheral ganglia.

\subsection{Glial syncytia}

As mentioned above, astrocytes form syncytia through gap junctions, which allow the flow of second messengers, metabolites and ions. Electron microscopic studies have shown the presence of gap junction in SGCs in DRG. These gap junctions may couple several SGCs, and also may connect different parts of the same cell (similarly to reflexive gap junctions in astrocytes). Dye coupling studies have directly demonstrated that SGCs are interconnected by gap junctions [53] These inter-SGC gap junctions are assembled from $\mathrm{Cx} 43[54,55]$; in addition, both DRG neurons and SGCs contain Cx36 [56].

\subsection{Immune properties}

Astrocytes possess certain properties of immune cells, for example they can perform phagocytosis [57], and act as antigen presenting cells (APC) [58, 59]. Satellite glia are quite similar in this respect. They too, demonstrate several immune cells characteristics; in particular SGCs in several species are able to phagocyte [38]. In the human trigeminal ganglia SGCs not only perform phagocytosis but also act as APC [60]. These SGCs even express several markers of macrophages including MHC type II, CD40, and CD54, but not CD14 and CD68, and thus appear to have a unique phenotype similar to that of leukocytes [60]. 


\section{Comparative physiology of astrocytes and satellite glia}

\subsection{Receptors}

Experiments in vitro, in cell cultures, demonstrated that astrocytes are potentially capable of expressing all types of receptors to neurotransmitters (both ionotropic and metabotropic, Fig. 2) and neurohormones [61-65]. At the same time, expression of these receptors in the tissue in situ and in vivo is restricted and controlled by a local neurochemical environment, so that astrocytes specifically express receptors congruent with the neurotransmitters released in their vicinity $[6,17]$.

Knowledge on the receptor repertoire in SGCs remains limited (Fig. 2). Most of the information on SGC receptors is related to P2 purinergic receptors [66], and it was shown that neurons and SGCs mutually communicate via these receptors. Experiments on SGCs in trigeminal ganglion preparation and in culture revealed rather widespread expression of metabotropic purinoceptors represented by

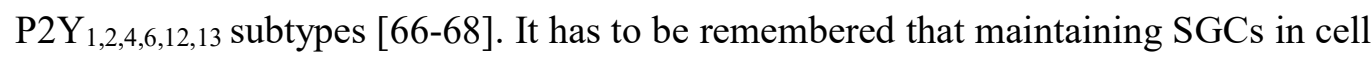
cultures [67] may alter cell properties including expression of various receptors [69]. Functional ionotropic purinoceptors of $\mathrm{P}_{2} \mathrm{X}_{7}$ type were found in SGCs in rodent sensory ganglia [70-74] as well as in human DRG [71]. Purinergic transmission appears to have a major role in intercellular communications in sensory ganglia, in particular for neuron-SGC interactions and $\mathrm{Ca}^{2+}$ signaling $[75,76]$.

In addition, SGCs are highly sensitive to endothelin: the threshold of endothelin-1 (ET-1) to evoke $\mathrm{Ca}^{2+}$ response in SGCs in mouse trigeminal and nodose ganglia is around $0.1 \mathrm{nM}$. Endothelin acts mainly through the stimulation of $\mathrm{ET}_{\mathrm{B}}$ receptors in trigeminal ganglia and mixture of $\mathrm{ET}_{\mathrm{A}}$ and $\mathrm{ET}_{\mathrm{B}}$ receptors in nodose ganglia $[77,78]$. Sensory neurons contain endothelin, but whether and how this peptide may contribute to neuron-SGC communication remains unknown.

Neurons in sensory ganglia contain the NO-synthesizing enzyme NO synthase [79]. Upon excitation, neurons produce NO, which diffuses to the adjacent SGCs, which contain the enzyme soluble guanylate cyclase (sGC), which is activated by NO. This leads to the production of cGMP in SGCs, and apparently causes their activation [80]. 
Incidentally, astrocytes express nitric oxide synthase and release NO, contributing to neuronal astrocyte communications [81]; in contrast, NO synthase is not found in SGCs. Conceptually, both astrocytes and SGCs sense and respond to substances released from neurons near them, but due to the great diversity of bioactive molecules in the CNS, astrocytes possess richer and much more heterogeneous receptors patterns. Nonetheless, much remains to be learned about SGC receptors, especially in non-rodent species.

\subsection{Transporters}

Astrocytes express rich repertoire of plasmalemmal transporters, which underlie their homeostatic capabilities [6, 19]. The glutamate/glutamine transporters are of particular importance as they support glutamine-glutamate shuttle, which is indispensable for glutamatergic and GABA-ergic neurotransmission (Fig. 2) [82-84]. Both glutamate and GABA transports were identified in SGCs in sensory ganglia. In particular excitatory amino acid transporter 1 (EAAT1, also known as GLAST) was identified in SGCs in sensory ganglia $[54,85]$. In addition, similarly to astrocytes, SGCs contain the enzyme glutamine synthetase [86], which converts glutamate into glutamine, being thus a central component for the glutamate-glutamine shuttle. Whether this shuttle operates in the peripheral ganglia remains an unanswered question. Another fundamental function of astroglia is control over homeostasis of extracellular $\mathrm{K}^{+}$, which is accomplished through active transport mediated by $\mathrm{Na}^{+} / \mathrm{K}^{+}$ ATPase and subsequent return of $\mathrm{K}^{+}$back to extracellular through $\mathrm{K}_{\mathrm{ir}} 4.1$ channels [87, 88.Breslin, $2018 \# 144]$. The SGCs express $\mathrm{Na}^{+} / \mathrm{K}^{+}$ATPase [89], however whether it contributes to $\mathrm{K}+$ buffering in the perineuronal space remains unknown, though likely.

\subsection{Ionic signaling}

All glial cells are electrically non-excitable; and all of them employ specific type of intercellular signaling mediated by spatially and temporally organized changes in the concentration of ions or second messengers [17]. The signaling role for $\mathrm{Ca}^{2+}$ and $\mathrm{Na}^{+}$ in astrocytes is well characterized, whereas the signaling role for $\mathrm{K}^{+}$and $\mathrm{Cl}^{-}$is being considered [90]. Evidence for $\mathrm{Ca}^{2+}$ signaling and propagating " $\mathrm{Ca}^{2+}$ waves" in SGCs 
is quite limited, and so far they have described only for trigeminal SGCs in culture $[76,91]$. These $\mathrm{Ca}^{2+}$ signals and $\mathrm{Ca}^{2+}$ waves are strongly dependent on extracellular ATP, with some contribution of gap junctions, and thus are similar to propagating $\mathrm{Ca}^{2+}$ signals in astrocytes in culture and in acute brain slices. Whether SGCs possess other forms of intracellular excitability remains to be studied.

\subsection{Chemo- and mechano-sensory functions}

Astrocytes in different regions of the brain are acting as chemosensors capable of monitoring fluctuations of several vital molecules. Astrocytes are sensitive to changes in $\mathrm{pO}_{2}$, and are activated when $\mathrm{pO}_{2}$ decreases below $17 \mathrm{~mm} \mathrm{Hg}$; in comparison, glomus cells in the carotid body are more sensitive, beingactivated when $\mathrm{pO}_{2}$ decreases below $50 \mathrm{~mm} \mathrm{Hg}$ [92]. The oxygen sensor has been identified in astrocytes throughout the brain, in cortex, hippocampus, midbrain and brain stem [92]. Decrease in $\mathrm{pO}_{2}$ triggers astrocytic $\mathrm{Ca}^{2+}$ signaling, which evoke ATP secretion and activation of neurons responsible for respiration. In the retrotrapezoid nucleus of the brainstem astrocytes mount $\mathrm{Ca}^{2+}$ responses with subsequent ATP secretion in response to decreases in $\mathrm{pH}$ by 0.2. - 0.4 units [93]; this type of chemosensitivity is selectively expressed in brain stem astroglia $[94,95]$. Mechanistic link between $\mathrm{pH}$ and astrocyte $\mathrm{Ca}^{2+}$ signaling is provided by the $\mathrm{Na}^{+}$-bicarbonate transporter $\mathrm{NBC} 1$; decrease in $\mathrm{pH}$ activates this transporter, thus initiating $\mathrm{Na}^{+}$influx; the latter increases $\left[\mathrm{Na}^{+}\right]_{\mathrm{i}}$ which reverses $\mathrm{Na}^{+} / \mathrm{Ca}^{2+}$ exchanger [96]. Astrocytes in the subfornical organ act as systemic $\mathrm{Na}^{+}$-sensors. This is mediated by specific $\mathrm{Na}_{\mathrm{x}}$ channel sensitive to extracellular $\left[\mathrm{Na}^{+}\right]$; when $\left[\mathrm{Na}^{+}\right]$in the blood rises above $140 \mathrm{mM}$ the $\mathrm{Na}_{\mathrm{x}}$ becomes activated, which triggers increase in lactate production; lactate acts on neighboring neurons to initiate a systemic $\mathrm{Na}^{+}$-homeostatic response [97-99]. Astrocytes of the brain stem also act as mechanosensors, this being mediated by complex interactions between $\mathrm{Cx} 43$ hemichannels, TRPV1 channels and $\mathrm{P}_{2} \mathrm{Y}_{1}$ purinoceptors [100].

As sensory ganglia are exposed to the circulation, SGCs might similarly sense changes in the contents of the blood. The DRG neurons has been proposed to have a chemosensory role and can send to the CNS a continuous stream of information on the contents of the systemic circulation in physiological and pathological contexts [101]. As neurons are covered with SGC sheath, SGCs are the first to be exposed to 
chemical changes in the blood, and it was suggested that SGCs too, may have a chemosensory role [40], receiving chemical signals, and conveying messages to neurons. Surprisingly, nothing is known about this aspect of SGCs. The SGCs may also sense changes in pressure. In particular this might be relevant for cells in trigeminal ganglia, which are located in the cranium; where both neurons and SGCs may be subjected changes in cranial pressure. However intriguing, this remains a speculation, as currently there are no reports on this topic, and this is an open field.

\section{Comparative pathophysiology of astrocytes and satellite glia}

It is a truth universally acknowledged that neuroglia contribute to all neurological diseases. This contribution can be primary, when changes in glial cells drive pathology, or secondary, when changes in glial cells are caused by pathological changes in the surrounding tissues. Astrogliopathology is represented by several pathophysiological entities, which include astrocytic atrophy and loss of function, astroglial reactivity, astrodegeneration and astroglial pathological remodeling [102106]. Astroglial reactivity is a defensive and evolutionary conserved response, which, through biochemical, molecular and functional changes aims to preserve the homeostasis of the lesioned nervous tissue and support neuroprotection and postlesion regeneration [107, 108]. Astroglial atrophy with loss of function is widely present in neuropsychiatric and some neurodegenerative diseases [104, 109], while astroglial pathological remodeling is associated with genetic or acquired metamorphoses of astrocytes, which cause and drive neuropathology [110, 111].

There is evidence for the contribution of spinal cord astrocytes to chronic pain [7]. An injury to peripheral nerves is a common pain model where both the spinal cord (and sensory ganglia) are affected. Such injuries induce reactive astrogliosis in the spinal cord, which is accompanied by increased expression of $\mathrm{Cx} 43$ and release of proinflammtory cytokines. It has been suggested that these reactive astrocytes can drive pain, with augmented expression of $\mathrm{Cx} 43$ being essential for maintaining neuropathic pain [7]. These arguments are based on observations on the dorsal horn of the spinal cord, but there is evidence that astrocytes in supraspinal regions play a role in chronic pain $[112,113]$. 
The pathophysiology of SGCs is much less explored; with most data derived from various models of neuropathic or inflammatory pain. Changes in SGCs contribute to neuropathic pain, as demonstrated by numerous studies of both local and systemic injuries. Several studies have shown that nerve injury upregulates $\mathrm{Cx} 43$ expression in trigeminal ganglia, which may contribute to pain [54, 114-116]; changes in other Cxs have been also reported. For example, the expression of Cx26 connecting SGCs and neurons is transiently upregulated in trigeminal ganglia following peripheral capsaicin injection, and was sustained in an inflammatory pain model [117]. Expression of Cx36 was also upregulated in neurons, but changes in $\mathrm{Cx} 43$ expression were not detected [117]. In contrast, Cx36 was downregulated in rat DRG after sciatic nerve injury [56]. Under physiological conditions coupling is mostly confined to SGC surrounding an individual neuron, but after peripheral injury gap junctions are established between SGCs associated with different neurons within the ganglion [118120]. It was suggested that these augmented gap junctions contribute to chronic pain, and their blockade reduced pain $[37,54,117,121]$. In agreement with this, reduction in Cx43 expression in trigeminal ganglia SGCs had an algesic action [54, 122], similar to the findings for astrocytes. This topic deserves further study because, as connexins can be therapeutic targets, different connexin subtypes may be blocked by different drugs [123].

It is noteworthy that under a large variety of pathological conditions, SGCs are affected in a rather uniform manner: GFAP upregulation [91, 124-126], upregulation of gap junctions as described above, and increased sensitivity of $\mathrm{P} 2$ purinoceptors [37, $54,116,120]$. These uniform changes arguably reflect a generic response of SGCs comparable with reactive gliosis in the CNS, and hence we may introduce the concept of reactive SGCs. Increase in expression of purinoceptors and connexins may lead to stronger $\mathrm{Ca}^{2+}$ signals and waves and therefore to greater neuronal and glial responses to ATP. The resulting increase in neuronal excitability is likely to contribute to pain $[37,121]$.

Injury triggers SGCs reactivity through the release of nitric oxide from DRG neurons [80]. This finding is highly pertinent for identifying effective pain therapy because preventing gliosis is, arguably, a much more effective way to treat pain than targeting one or more of the numerous downstream changes associated with gliosis. Moreover, 
focusing on earlier changes that take place in sensory ganglia, and preventing SGCs activation - possibly by blocking the NO-cGMP pathway - is a more rational way to approach pain therapy, particularly because abnormal peripheral nerve activity drives central sensitization. Another crucial factor against aiming drugs at the CNS is the presence of the BBB, which prevents the entry of most drugs into the CNS. In contrast, such barrier is absence in sensory ganglia, making them ideal targets for drug therapy.

\section{Conclusion}

Astrocytes fulfill many functions in the CNS. In comparison to astrocytes, SGCs are less diverse and display more limited functional capabilities. Nevertheless, many aspects of SGCs have not been explored at all, and we anticipate that growing interest in these cells may lead to discoveries of new functions, revealing more facets of these cells in physiology and pathology.

Conflict of interest: The authors declare no conflict of interest.

Author contributions: $\mathrm{MH}$ and $\mathrm{AV}$ wrote and edited the article.

Data Availability: There are no data associated with this article. 


\section{References}

[1] A. Verkhratsky, A.M. Butt, (2013) Glial Physiology and Pathophysiology, WileyBlackwell, Chichester.

[2] K.R. Jessen, R. Mirsky, (2005) The origin and development of glial cells in peripheral nerves, Nat Rev Neurosci, 6: 671-682 doi: 10.1038/nrn1746.

[3] N. Le Douarin, C. Dulac, E. Dupin, P. Cameron-Curry, (1991) Glial cell lineages in the neural crest, Glia, 4: 175-184 doi: 10.1002/glia.440040209.

[4] J.B. Zuchero, B.A. Barres, (2015) Glia in mammalian development and disease, Development, 142: 3805-3809 doi: 10.1242/dev.129304.

[5] K.A. Nave, (2010) Myelination and the trophic support of long axons, Nat Rev Neurosci, 11: 275-283 doi: 10.1038/nrn2797.

[6] A. Verkhratsky, M. Nedergaard, (2018) Physiology of Astroglia, Physiol Rev, 98: 239-389 doi: 10.1152/physrev.00042.2016.

[7] R.R. Ji, C.R. Donnelly, M. Nedergaard, (2019) Astrocytes in chronic pain and itch, Nat Rev Neurosci, 20: 667-685 doi: 10.1038/s41583-019-0218-1.

[8] E. Mayr, (1982) The Growth of Biological Thought, Harvard U.P, Cambridge (Mass.).

[9] C. Golgi, (1903) Opera Omnia, Hoepli, Milano.

[10] S.R. Ramon-y-Cajal, (1899) Textura del Sistema Nervioso del Hombre y de los Vertebrados. Translation: Texture of the Nervous System of Man and the Vertebrates, Springer, New York.

[11] C.L. Schleich, (1894) Schmerzlose Operationen: Örtliche Betäubung mit indiffrenten Flüssigkeiten. Psychophysik des natürlichen und künstlichen Schlafes., Julius Springer, Berlin.

[12] R. Ambalavanar, M. Moritani, D. Dessem, (2005) Trigeminal P2X 3 receptor expression differs from dorsal root ganglion and is modulated by deep tissue inflammation, Pain, 117: 280-291 doi: 10.1016/j.pain.2005.06.029.

[13] S.E. Jager, L.T. Pallesen, M. Richner, P. Harley, Z. Hore, S. McMahon, F. Denk, C.B. Vaegter, (2020) Changes in the transcriptional fingerprint of satellite glial cells following peripheral nerve injury, Glia, 68: 1375-1395 doi: 10.1002/glia.23785.

[14] E.A. Bushong, M.E. Martone, Y.Z. Jones, M.H. Ellisman, (2002) Protoplasmic astrocytes in CA1 stratum radiatum occupy separate anatomical domains, J Neurosci, 22: 183-192 doi: 
[15] C. Iadecola, (2017) The Neurovascular Unit Coming of Age: A Journey through Neurovascular Coupling in Health and Disease, Neuron, 96: 17-42 doi: 10.1016/j.neuron.2017.07.030.

[16] B.S. Khakh, M.V. Sofroniew, (2015) Diversity of astrocyte functions and phenotypes in neural circuits, Nat Neurosci, 18: 942-952 doi: 10.1038/nn.4043.

[17] A. Verkhratsky, A. Semyanov, R. Zorec, (2020) Physiology of astroglial excitability, Function, 1: zqaa016 doi: 10.1093/function/zqaa016.

[18] N. Gavrilov, I. Golyagina, A. Brazhe, A. Scimemi, V. Turlapov, A. Semyanov, (2018) Astrocytic Coverage of Dendritic Spines, Dendritic Shafts, and Axonal Boutons in Hippocampal Neuropil, Front Cell Neurosci, 12: 248 doi: 10.3389/fncel.2018.00248.

[19] A. Verkhratsky, C.R. Rose, (2020) $\mathrm{Na}^{+}$-dependent transporters: The backbone of astroglial homeostatic function, Cell Calcium, 85: 102136 doi: 10.1016/j.ceca.2019.102136.

[20] C.R. Rose, A. Verkhratsky, (2016) Principles of sodium homeostasis and sodium signalling in astroglia, Glia, 64: 1611-1627 doi: 10.1002/glia.22964.

[21] A. Verkhratsky, M. Nedergaard, (2014) Astroglial cradle in the life of the synapse, Philos Trans R Soc Lond B Biol Sci, 369: 20130595 doi: 10.1098/rstb.2013.0595.

[22] M. Nedergaard, A. Verkhratsky, (2012) Artifact versus reality - how astrocytes contribute to synaptic events, Glia, 60: 1013-1023 doi: 10.1002/glia.22288.

[23] C. Giaume, A. Koulakoff, L. Roux, D. Holcman, N. Rouach, (2010) Astroglial networks: a step further in neuroglial and gliovascular interactions, Nat Rev Neurosci, 11: 87-99 doi: 10.1038/nrn2757.

[24] V. Houades, A. Koulakoff, P. Ezan, I. Seif, C. Giaume, (2008) Gap junctionmediated astrocytic networks in the mouse barrel cortex, J Neurosci, 28: 5207-5217 doi: 10.1523/JNEUROSCI.5100-07.2008.

[25] C. Giaume, C.C. Naus, J.C. Saez, L. Leybaert, (2021) Glial Connexins and Pannexins in the Healthy and Diseased Brain, Physiol Rev, 101: 93-145 doi: 10.1152/physrev.00043.2018.

[26] C. Giaume, C. Fromaget, A. el Aoumari, J. Cordier, J. Glowinski, D. Gros, (1991) Gap junctions in cultured astrocytes: single-channel currents and characterization of channel-forming protein, Neuron, 6: 133-143 doi: 
[27] J.I. Nagy, X. Li, J. Rempel, G. Stelmack, D. Patel, W.A. Staines, T. Yasumura, J.E. Rash, (2001) Connexin26 in adult rodent central nervous system: demonstration at astrocytic gap junctions and colocalization with connexin30 and connexin43, J Comp Neurol, 441: 302-323 doi:

[28] J.I. Nagy, F.E. Dudek, J.E. Rash, (2004) Update on connexins and gap junctions in neurons and glia in the mammalian nervous system, Brain Res Brain Res Rev, 47: 191-215 doi: 10.1016/j.brainresrev.2004.05.005.

[29] L. Hertz, M.E. Gibbs, G.A. Dienel, (2014) Fluxes of lactate into, from, and among gap junction-coupled astrocytes and their interaction with noradrenaline, Front Neurosci, 8: 261 doi: 10.3389/fnins.2014.00261.

[30] N. Rouach, A. Koulakoff, V. Abudara, K. Willecke, C. Giaume, (2008) Astroglial metabolic networks sustain hippocampal synaptic transmission, Science, 322: 1551-1555 doi: 10.1126/science. 1164022 .

[31] T.M. Mathiisen, K.P. Lehre, N.C. Danbolt, O.P. Ottersen, (2010) The perivascular astroglial sheath provides a complete covering of the brain microvessels: an electron microscopic 3D reconstruction, Glia, 58: 1094-1103 doi: 10.1002/glia.20990.

[32] S.L. Feig, L.B. Haberly, (2011) Surface-associated astrocytes, not endfeet, form the glia limitans in posterior piriform cortex and have a spatially distributed, not a domain, organization, J Comp Neurol, 519: 1952-1969 doi: 10.1002/cne.22615.

[33] M.D. Sweeney, Z. Zhao, A. Montagne, A.R. Nelson, B.V. Zlokovic, (2019) Blood-Brain Barrier: From Physiology to Disease and Back, Physiol Rev, 99: 21-78 doi: 10.1152/physrev.00050.2017.

[34] S.J. Mulligan, B.A. MacVicar, (2004) Calcium transients in astrocyte endfeet cause cerebrovascular constrictions, Nature, 431: 195-199 doi: 10.1038/nature02827 nature 02827.

[35] M. Zonta, M.C. Angulo, S. Gobbo, B. Rosengarten, K.A. Hossmann, T. Pozzan, G. Carmignoto, (2003) Neuron-to-astrocyte signaling is central to the dynamic control of brain microcirculation, Nat Neurosci, 6: 43-50 doi: 10.1038/nn980 nn980 [pii].

[36] C. Iadecola, M. Nedergaard, (2007) Glial regulation of the cerebral microvasculature, Nat Neurosci, 10: 1369-1376 doi: 10.1038/nn2003. 
[37] M. Hanani, D.C. Spray, (2020) Emerging importance of satellite glia in nervous system function and dysfunction, Nat Rev Neurosci, 21: 485-498 doi: 10.1038/s41583-020-0333-z.

[38] E. Pannese, (2018) Biology and Pathology of Perineuronal Satellite Cells in Sensory Ganglia, Adv. Anat. Embryol. Cell Biol., 226: 1-83 doi: 10.1007/978-3319-60140-3.

[39] P. Hu, E.M. McLachlan, (2002) Macrophage and lymphocyte invasion of dorsal root ganglia after peripheral nerve lesions in the rat, Neuroscience, 112: 23-38 doi: 10.1016/s0306-4522(02)00065-9.

[40] M. Hanani, (2005) Satellite glial cells in sensory ganglia: from form to function, Brain Res Brain Res Rev, 48: 457-476 doi: 10.1016/j.brainresrev.2004.09.001.

[41] L. Kubicek, R. Kopacik, I. Klusakova, P. Dubovy, (2010) Alterations in the vascular architecture of the dorsal root ganglia in a rat neuropathic pain model, Ann Anat, 192: 101-106 doi: 10.1016/j.aanat.2010.01.005.

[42] H. Faber-Zuschratter, K. Huttmann, C. Steinhauser, A. Becker, J. Schramm, U. Okafo, D. Shanley, D.M. Yilmazer-Hanke, (2009) Ultrastructural and functional characterization of satellitosis in the human lateral amygdala associated with Ammon's horn sclerosis, Acta Neuropathol, 117: 545-555 doi: 10.1007/s00401-0090504-5.

[43] C. Takasaki, M. Yamasaki, M. Uchigashima, K. Konno, Y. Yanagawa, M. Watanabe, (2010) Cytochemical and cytological properties of perineuronal oligodendrocytes in the mouse cortex, Eur J Neurosci, 32: 1326-1336 doi: 10.1111/j.1460-9568.2010.07377.x.

[44] J.R. Wolff, T.L. Chao, (2004) Cytoarchitectonics of non-neuronal cells in the central nervous system, Adv Molec Cell Biol, 31: 1-51 doi:

[45] Y.C. Li, L.K. Sun, L. Zhou, H.N. Zhang, (2011) Clarification of the peripherally located F-actin network around the primary afferent neurons, Brain Res, 1392: 54-61 doi: 10.1016/j.brainres.2011.03.063.

[46] E. Pannese, P. Procacci, M. Ledda, (1996) Ultrastructural localization of actin in the cell body of rat spinal ganglion neurons, Anat Embryol (Berl), 194: 527-531 doi: 10.1007/BF00187466.

[47] N.A. Oberheim, T. Takano, X. Han, W. He, J.H. Lin, F. Wang, Q. Xu, J.D. Wyatt, W. Pilcher, J.G. Ojemann, B.R. Ransom, S.A. Goldman, M. Nedergaard, 
(2009) Uniquely hominid features of adult human astrocytes, J Neurosci, 29: 32763287 doi: 10.1523/JNEUROSCI.4707-08.2009.

[48] N.A. Oberheim, X. Wang, S. Goldman, M. Nedergaard, (2006) Astrocytic complexity distinguishes the human brain, Trends Neurosci, 29: 547-553 doi: 10.1016/j.tins.2006.08.004.

[49] A. Verkhratsky, N.A. Oberheim-Bush, M. Nedergaard, A. Butt, (2018) The special case of human astrocytes, Neuroglia: doi: 0.3390/neuroglia1010004.

[50] E. Pannese, M. Ledda, G. Arcidiacono, L. Rigamonti, (1991) Clusters of nerve cell bodies enclosed within a common connective tissue envelope in the spinal ganglia of the lizard and rat, Cell Tissue Res, 264: 209-214 doi: 10.1007/BF00313957.

[51] M. Ledda, S. De Palo, E. Pannese, (2004) Ratios between number of neuroglial cells and number and volume of nerve cells in the spinal ganglia of two species of reptiles and three species of mammals, Tissue Cell, 36: 55-62 doi: 10.1016/j.tice.2003.09.001.

[52] E. Pannese, (2002) Perikaryal surface specializations of neurons in sensory ganglia, Int Rev Cytol, 220: 1-34 doi: 10.1016/s0074-7696(02)20002-9.

[53] M. Hanani, (2012) Intercellular communication in sensory ganglia by purinergic receptors and gap junctions: implications for chronic pain, Brain Res, 1487: 183-191 doi: 10.1016/j.brainres.2012.03.070.

[54] P.T. Ohara, J.P. Vit, A. Bhargava, L. Jasmin, (2008) Evidence for a role of connexin 43 in trigeminal pain using RNA interference in vivo, J Neurophysiol, 100: 3064-3073 doi: 10.1152/jn.90722.2008.

[55] P. Procacci, V. Magnaghi, E. Pannese, (2008) Perineuronal satellite cells in mouse spinal ganglia express the gap junction protein connexin43 throughout life with decline in old age, Brain Res Bull, 75: 562-569 doi: 10.1016/j.brainresbull.2007.09.007.

[56] E.M. Perez Armendariz, M. Norcini, B. Hernandez-Tellez, A. Castell-Rodriguez, C. Coronel-Cruz, R.G. Alquicira, A. Sideris, E. Recio-Pinto, (2018) Neurons and satellite glial cells in adult rat lumbar dorsal root ganglia express connexin 36, Acta Histochem, 120: 168-178 doi: 10.1016/j.acthis.2017.11.005.

[57] H. Konishi, T. Okamoto, Y. Hara, O. Komine, H. Tamada, M. Maeda, F. Osako, M. Kobayashi, A. Nishiyama, Y. Kataoka, T. Takai, N. Udagawa, S. Jung, K. Ozato, T. Tamura, M. Tsuda, K. Yamanaka, T. Ogi, K. Sato, H. Kiyama, (2020) Astrocytic 
phagocytosis is a compensatory mechanism for microglial dysfunction, EMBO J, 39: e104464 doi: 10.15252/embj.2020104464.

[58] J. Rostami, G. Fotaki, J. Sirois, R. Mzezewa, J. Bergstrom, M. Essand, L. Healy, A. Erlandsson, (2020) Astrocytes have the capacity to act as antigen-presenting cells in the Parkinson's disease brain, J Neuroinflammation, 17: 119 doi: 10.1186/s12974020-01776-7.

[59] C.S. Constantinescu, M. Tani, R.M. Ransohoff, M. Wysocka, B. Hilliard, T. Fujioka, S. Murphy, P.J. Tighe, J. Das Sarma, G. Trinchieri, A. Rostami, (2005) Astrocytes as antigen-presenting cells: expression of IL-12/IL-23, J Neurochem, 95: 331-340 doi: 10.1111/j.1471-4159.2005.03368.x.

[60] M. van Velzen, J.D. Laman, A. Kleinjan, A. Poot, A.D. Osterhaus, G.M. Verjans, (2009) Neuron-interacting satellite glial cells in human trigeminal ganglia have an APC phenotype, J Immunol, 183: 2456-2461 doi: 10.4049/jimmunol.0900890.

[61] A. Verkhratsky, R.K. Orkand, H. Kettenmann, (1998) Glial calcium: homeostasis and signaling function, Physiol Rev, 78: 99-141 doi:

[62] A. Verkhratsky, C. Steinhauser, (2000) Ion channels in glial cells, Brain Res Brain Res Rev, 32: 380-412 doi: 10.1016/s0165-0173(99)00093-4.

[63] U. Lalo, Y. Pankratov, V. Parpura, A. Verkhratsky, (2011) Ionotropic receptors in neuronal-astroglial signalling: what is the role of "excitable" molecules in nonexcitable cells, Biochim Biophys Acta, 1813: 992-1002 doi: 10.1016/j.bbamcr.2010.09.007.

[64] J.T. Porter, K.D. McCarthy, (1997) Astrocytic neurotransmitter receptors in situ and in vivo, Prog Neurobiol, 51: 439-455 doi:

[65] H.K. Kimelberg, (1995) Receptors on astrocytes--what possible functions?, Neurochem Int, 26: 27-40 doi: 10.1016/0197-0186(94)00118-e.

[66] M. Weick, P.S. Cherkas, W. Hartig, T. Pannicke, O. Uckermann, A. Bringmann, M. Tal, A. Reichenbach, M. Hanani, (2003) P2 receptors in satellite glial cells in trigeminal ganglia of mice, Neuroscience, 120: 969-977 doi: 10.1016/s03064522(03)00388-9.

[67] S. Ceruti, M. Fumagalli, G. Villa, C. Verderio, M.P. Abbracchio, (2008) Purinoceptor-mediated calcium signaling in primary neuron-glia trigeminal cultures, Cell Calcium, 43: 576-590 doi: 10.1016/j.ceca.2007.10.003.

[68] G. Magni, S. Ceruti, (2014) The purinergic system and glial cells: emerging costars in nociception, Biomed Res Int, 2014: 495789 doi: 10.1155/2014/495789. 
[69] V. Belzer, N. Shraer, M. Hanani, (2010) Phenotypic changes in satellite glial cells in cultured trigeminal ganglia, Neuron Glia Biol, 6: 237-243 doi: 10.1017/S1740925X1100007X.

[70] R. Kushnir, P.S. Cherkas, M. Hanani, (2011) Peripheral inflammation upregulates P2X receptor expression in satellite glial cells of mouse trigeminal ganglia: a calcium imaging study, Neuropharmacology, 61: 739-746 doi: 10.1016/j.neuropharm.2011.05.019.

[71] I.P. Chessell, J.P. Hatcher, C. Bountra, A.D. Michel, J.P. Hughes, P. Green, J. Egerton, M. Murfin, J. Richardson, W.L. Peck, C.B. Grahames, M.A. Casula, Y. Yiangou, R. Birch, P. Anand, G.N. Buell, (2005) Disruption of the P2X 7 purinoceptor gene abolishes chronic inflammatory and neuropathic pain, Pain, 114: 386-396 doi: 10.1016/j.pain.2005.01.002.

[72] S. Liu, L. Zou, J. Xie, W. Xie, S. Wen, Q. Xie, Y. Gao, G. Li, C. Zhang, C. Xu, H. Xu, B. Wu, Q. Lv, X. Zhang, S. Wang, Y. Xue, S. Liang, (2016) LncRNA NONRATT021972 siRNA regulates neuropathic pain behaviors in type 2 diabetic rats through the $\mathrm{P} 2 \mathrm{X} 7$ receptor in dorsal root ganglia, Mol Brain, 9: 44 doi: 10.1186/s13041-016-0226-2.

[73] J. Song, Y. Ying, W. Wang, X. Liu, X. Xu, X. Wei, X. Ruan, (2018) The role of $\mathrm{P} 2 \mathrm{X} 7 \mathrm{R} / \mathrm{ERK}$ signaling in dorsal root ganglia satellite glial cells in the development of chronic postsurgical pain induced by skin/muscle incision and retraction (SMIR), Brain Behav Immun, 69: 180-189 doi: 10.1016/j.bbi.2017.11.011.

[74] X. Zhang, Y. Chen, C. Wang, L.Y. Huang, (2007) Neuronal somatic ATP release triggers neuron-satellite glial cell communication in dorsal root ganglia, Proc Natl Acad Sci U S A, 104: 9864-9869 doi: 10.1073/pnas.0611048104.

[75] L.Y. Huang, Y. Gu, Y. Chen, (2013) Communication between neuronal somata and satellite glial cells in sensory ganglia, Glia, 61: 1571-1581 doi: 10.1002/glia.22541.

[76] S.O. Suadicani, P.S. Cherkas, J. Zuckerman, D.N. Smith, D.C. Spray, M. Hanani, (2010) Bidirectional calcium signaling between satellite glial cells and neurons in cultured mouse trigeminal ganglia, Neuron Glia Biol, 6: 43-51 doi: 10.1017/S1740925X09990408.

[77] R. Feldman-Goriachnik, M. Hanani, (2017) The effects of endothelin-1 on satellite glial cells in peripheral ganglia, Neuropeptides, 63: 37-42 doi: 10.1016/j.npep.2017.03.002. 
[78] R. Feldman-Goriachnik, M. Hanani, (2011) Functional study of endothelin B receptors in satellite glial cells in trigeminal ganglia, Neuroreport, 22: 465-469 doi: 10.1097/WNR.0b013e3283472487.

[79] T. Thippeswamy, R. Morris, (2001) Evidence that nitric oxide-induced synthesis of cGMP occurs in a paracrine but not an autocrine fashion and that the site of its release can be regulated: studies in dorsal root ganglia in vivo and in vitro, Nitric Oxide, 5: 105-115 doi: 10.1006/niox.2001.0316.

[80] V. Belzer, M. Hanani, (2019) Nitric oxide as a messenger between neurons and satellite glial cells in dorsal root ganglia, Glia, 67: 1296-1307 doi: 10.1002/glia.23603.

[81] Y. Amitai, (2010) Physiologic role for "inducible" nitric oxide synthase: a new form of astrocytic-neuronal interface, Glia, 58: 1775-1781 doi: 10.1002/glia.21057.

[82] L. Hertz, (2013) The glutamate-glutamine (GABA) cycle: importance of late postnatal development and potential reciprocal interactions between biosynthesis and degradation, Front Endocrinol (Lausanne), 4: 59 doi: 10.3389/fendo.2013.00059.

[83] N.C. Danbolt, (2001) Glutamate uptake, Prog Neurobiol, 65: 1-105 doi:

[84] Y. Zhou, N.C. Danbolt, (2013) GABA and glutamate transporters in brain, Front Endocrinol (Lausanne), 4: 165 doi: 10.3389/fendo.2013.00165.

[85] U.V. Berger, M.A. Hediger, (2000) Distribution of the glutamate transporters GLAST and GLT-1 in rat circumventricular organs, meninges, and dorsal root ganglia, J Comp Neurol, 421: 385-399 doi: 10.1002/(sici)1096-9861(20000605)421:3. [86] K.E. Miller, B.A. Richards, R.M. Kriebel, (2002) Glutamine-, glutamine synthetase-, glutamate dehydrogenase- and pyruvate carboxylase-immunoreactivities in the rat dorsal root ganglion and peripheral nerve, Brain Res, 945: 202-211 doi: 10.1016/s0006-8993(02)02802-0.

[87] B.R. Larsen, M. Assentoft, M.L. Cotrina, S.Z. Hua, M. Nedergaard, K. Kaila, J. Voipio, N. MacAulay, (2014) Contributions of the $\mathrm{Na}^{+} / \mathrm{K}^{+}$-ATPase, NKCC1, and $\mathrm{K}_{\mathrm{ir}} 4.1$ to hippocampal $\mathrm{K}^{+}$clearance and volume responses, Glia, 62: 608-622 doi: 10.1002/glia.22629.

[88] N. MacAulay, (2020) Molecular mechanisms of $\mathrm{K}^{+}$clearance and extracellular space shrinkage. Glia cells as the stars, Glia, 68: 2192-2211 doi: 10.1002/glia.23824.

[89] M.F. Arteaga, R. Gutierrez, J. Avila, A. Mobasheri, L. Diaz-Flores, P. MartinVasallo, (2004) Regeneration influences expression of the $\mathrm{Na}^{+}, \mathrm{K}^{+}$-atpase subunit 
isoforms in the rat peripheral nervous system, Neuroscience, 129: 691-702 doi: 10.1016/j.neuroscience.2004.08.041.

[90] A. Verkhratsky, V. Untiet, C.R. Rose, (2020) Ionic signalling in astroglia beyond calcium, J Physiol, 598: 1655-1670 doi: 10.1113/JP277478.

[91] R.A. Warwick, M. Hanani, (2013) The contribution of satellite glial cells to chemotherapy-induced neuropathic pain, Eur J Pain, 17: 571-580 doi: 10.1002/j.15322149.2012.00219.x.

[92] P.R. Angelova, V. Kasymov, I. Christie, S. Sheikhbahaei, E. Turovsky, N. Marina, A. Korsak, J. Zwicker, A.G. Teschemacher, G.L. Ackland, G.D. Funk, S. Kasparov, A.Y. Abramov, A.V. Gourine, (2015) Functional oxygen sensitivity of astrocytes, J Neurosci, 35: 10460-10473 doi: 10.1523/JNEUROSCI.0045-15.2015. [93] A.V. Gourine, V. Kasymov, N. Marina, F. Tang, M.F. Figueiredo, S. Lane, A.G. Teschemacher, K.M. Spyer, K. Deisseroth, S. Kasparov, (2010) Astrocytes control breathing through pH-dependent release of ATP, Science, 329: 571-575 doi: 10.1126/science. 1190721 .

[94] V. Kasymov, O. Larina, C. Castaldo, N. Marina, M. Patrushev, S. Kasparov, A.V. Gourine, (2013) Differential sensitivity of brainstem versus cortical astrocytes to changes in $\mathrm{pH}$ reveals functional regional specialization of astroglia, $\mathrm{J}$ Neurosci, 33: 435-441 doi: 10.1523/JNEUROSCI.2813-12.2013.

[95] P.G. Guyenet, R.L. Stornetta, G. Souza, S.B.G. Abbott, Y. Shi, D.A. Bayliss, (2019) The Retrotrapezoid Nucleus: Central Chemoreceptor and Regulator of Breathing Automaticity, Trends Neurosci, 42: 807-824 doi: 10.1016/j.tins.2019.09.002.

[96] E. Turovsky, S.M. Theparambil, V. Kasymov, J.W. Deitmer, A.G. Del Arroyo, G.L. Ackland, J.J. Corneveaux, A.N. Allen, M.J. Huentelman, S. Kasparov, N. Marina, A.V. Gourine, (2016) Mechanisms of $\mathrm{CO}_{2} / \mathrm{H}^{+}$sensitivity of astrocytes, J. Neurosci., 36: 10750-10758 doi:

[97] M. Noda, T.Y. Hiyama, (2015) The Nax channel: What it is and what it does, Neuroscientist, 21: 399-412 doi: 10.1177/1073858414541009.

[98] E. Watanabe, T.Y. Hiyama, H. Shimizu, R. Kodama, N. Hayashi, S. Miyata, Y. Yanagawa, K. Obata, M. Noda, (2006) Sodium-level-sensitive sodium channel Nax is expressed in glial laminate processes in the sensory circumventricular organs, Am J Physiol Regul Integr Comp Physiol, 290: R568-576 doi: 10.1152/ajpregu.00618.2005. 
[99] M. Noda, H. Sakuta, (2013) Central regulation of body-fluid homeostasis, Trends Neurosci, 36: 661-673 doi: 10.1016/j.tins.2013.08.004.

[100] E.A. Turovsky, A. Braga, Y. Yu, N. Esteras, A. Korsak, S.M. Theparambil, A. Hadjihambi, P.S. Hosford, A.G. Teschemacher, N. Marina, M.F. Lythgoe, P.G. Haydon, A.V. Gourine, (2020) Mechanosensory Signaling in Astrocytes, J Neurosci, 40: 9364-9371 doi: 10.1523/JNEUROSCI.1249-20.2020.

[101] M. Devor, (1999) Unexplained peculiarities of the dorsal rot ganglion., Pain, Suppl. 6: S27- S35 doi:

[102] M. Pekny, M. Pekna, A. Messing, C. Steinhauser, J.M. Lee, V. Parpura, E.M. Hol, M.V. Sofroniew, A. Verkhratsky, (2016) Astrocytes: a central element in neurological diseases, Acta Neuropathol, 131: 323-345 doi: 10.1007/s00401-0151513-1.

[103] A. Verkhratsky, V. Parpura, (2016) Astrogliopathology in neurological, neurodevelopmental and psychiatric disorders, Neurobiol Dis, 85: 254-261 doi: 10.1016/j.nbd.2015.03.025.

[104] A. Verkhratsky, J.J. Rodrigues, A. Pivoriunas, R. Zorec, A. Semyanov, (2019) Astroglial atrophy in Alzheimer's disease, Pflugers Arch, 471: 1247-1261 doi: 10.1007/s00424-019-02310-2.

[105] A. Verkhratsky, R. Zorec, V. Parpura, (2017) Stratification of astrocytes in healthy and diseased brain, Brain Pathol, 27: 629-644 doi: 10.1111/bpa.12537.

[106] V. Parpura, M.T. Heneka, V. Montana, S.H. Oliet, A. Schousboe, P.G. Haydon, R.F. Stout, Jr., D.C. Spray, A. Reichenbach, T. Pannicke, M. Pekny, M. Pekna, R. Zorec, A. Verkhratsky, (2012) Glial cells in (patho)physiology, J Neurochem, 121: 427 doi: 10.1111/j.1471-4159.2012.07664.x.

[107] M.V. Sofroniew, (2020) Astrocyte Reactivity: Subtypes, States, and Functions in CNS Innate Immunity, Trends Immunol, 41: 758-770 doi: 10.1016/j.it.2020.07.004.

[108] A. Escartin, E. Galea, A. Lakatos, J.P. O’Callaghan, G.C. Petzold, A. SerranoPozo, C. Steinhauser, A. Volterra, G. Carmignoto, A. Agarwal, N.J. Allen, A. Araque, L. Barbeito, A. Barzilai, D.E. Bergles, G. Bonvento, A.M. Butt, W.-T. Chen, M. Cohen-Salmon, C. Cunningham, B. Deneen, B. De Strooper, B. Díaz-Castro, C. Farina, M. Freeman, V. Gallo, J.E. Goldman, S.A. Goldman, M. Götz, A. Gutiérrez, P.G. Haydon, D.H. Heiland, E.M. Hol, M.G. Holt, M. Iino, K.V. Kastanenka, H. Kettenmann, B.S. Khakh, S. Koizumi, C.J. Lee, S.A. Liddelow, B.A. MacVicar, P. 
Magistretti, A. Messing, A. Mishra, A.V. Molofsky, K. Murai, C.M. Norris, S. Okada, S. Oliet, J.F. Oliveira, A. Panatier, V. Parpura, M. Pekna, M. Pekny, L. Pellerin, G. Perea, B.G. Pérez-Nievas, F.W. Pfrieger , K.E. Poskanzer, F.J. Quintana, R.M. Ransohoff, M. Riquelme-Perez, S. Robel, C.R. Rose, J. Rothstein, N. Rouach, D.H. Rowitch, A. Semyanov, S. Sirko, H. Sontheimer, R.A. Swanson, J. Vitorica, I.-B. Wanner, L.B. Wood, J. Wu, B. Zheng, R.E. Zimmer, R. Zorec, S. M.V., A. Verkhratsky, (2021) Consensus paper: Reactive astrocyte nomenclature, definitions, and future directions. , Nat Neurosci, in press: doi: 10.1038/s41593-020-00783-4.

[109] A. Verkhratsky, J.J. Rodriguez, L. Steardo, (2014) Astrogliopathology: a central element of neuropsychiatric diseases?, Neuroscientist, 20: 576-588 doi: $10.1177 / 1073858413510208$.

[110] A. Messing, M. Brenner, M.B. Feany, M. Nedergaard, J.E. Goldman, (2012) Alexander disease, J Neurosci, 32: 5017-5023 doi: 10.1523/JNEUROSCI.538411.2012.

[111] H. Chun, H. Im, Y.J. Kang, Y. Kim, J.H. Shin, W. Won, J. Lim, Y. Ju, Y.M. Park, S. Kim, S.E. Lee, J. Lee, J. Woo, Y. Hwang, H. Cho, S. Jo, J.H. Park, D. Kim, D.Y. Kim, J.S. Seo, B.J. Gwag, Y.S. Kim, K.D. Park, B.K. Kaang, H. Cho, H. Ryu, C.J. Lee, (2020) Severe reactive astrocytes precipitate pathological hallmarks of Alzheimer's disease via $\mathrm{H}_{2} \mathrm{O}_{2}{ }^{-}$production, Nat Neurosci, 23: 1555-1566 doi: 10.1038/s41593-020-00735-y.

[112] C.Y. Chiang, J.O. Dostrovsky, K. Iwata, B.J. Sessle, (2011) Role of glia in orofacial pain, Neuroscientist, 17: 303-320 doi: 10.1177/1073858410386801.

[113] A. Okada-Ogawa, I. Suzuki, B.J. Sessle, C.Y. Chiang, M.W. Salter, J.O. Dostrovsky, Y. Tsuboi, M. Kondo, J. Kitagawa, A. Kobayashi, N. Noma, Y. Imamura, K. Iwata, (2009) Astroglia in medullary dorsal horn (trigeminal spinal subnucleus caudalis) are involved in trigeminal neuropathic pain mechanisms, J Neurosci, 29: 11161-11171 doi: 10.1523/JNEUROSCI.3365-09.2009.

[114] Y.Z. Jin, P. Zhang, T. Hao, L.M. Wang, M.D. Guo, Y.H. Gan, (2019) Connexin 43 contributes to temporomandibular joint inflammation induced-hypernociception via sodium channel 1.7 in trigeminal ganglion, Neurosci Lett, 707: 134301 doi: 10.1016/j.neulet.2019.134301.

[115] H. Komiya, K. Shimizu, K. Ishii, H. Kudo, T. Okamura, K. Kanno, M. Shinoda, B. Ogiso, K. Iwata, (2018) Connexin 43 expression in satellite glial cells contributes to ectopic tooth-pulp pain, J Oral Sci, 60: 493-499 doi: 10.2334/josnusd.17-0452. 
[116] K. Kaji, M. Shinoda, K. Honda, S. Unno, N. Shimizu, K. Iwata, (2016) Connexin 43 contributes to ectopic orofacial pain following inferior alveolar nerve injury, Mol Pain, 12: doi: 10.1177/1744806916633704.

[117] F.G. Garrett, P.L. Durham, (2008) Differential expression of connexins in trigeminal ganglion neurons and satellite glial cells in response to chronic or acute joint inflammation., Neuron Glia Biol, 4: 295-306 doi:

[118] M. Hanani, T.Y. Huang, P.S. Cherkas, M. Ledda, E. Pannese, (2002) Glial cell plasticity in sensory ganglia induced by nerve damage, Neuroscience, 114: 279-283 doi: 10.1016/s0306-4522(02)00279-8.

[119] P.S. Cherkas, T.Y. Huang, T. Pannicke, M. Tal, A. Reichenbach, M. Hanani, (2004) The effects of axotomy on neurons and satellite glial cells in mouse trigeminal ganglion, Pain, 110: 290-298 doi: 10.1016/j.pain.2004.04.007.

[120] E. Blum, P. Procacci, V. Conte, M. Hanani, (2014) Systemic inflammation alters satellite glial cell function and structure. A possible contribution to pain, Neuroscience, 274: 209-217 doi: 10.1016/j.neuroscience.2014.05.029.

[121] D.C. Spray, M. Hanani, (2019) Gap junctions, pannexins and pain, Neurosci Lett, 695: 46-52 doi: 10.1016/j.neulet.2017.06.035.

[122] T.Y. Huang, V. Belzer, M. Hanani, (2010) Gap junctions in dorsal root ganglia: possible contribution to visceral pain, Eur J Pain, 14: 49 e41-11 doi: 10.1016/j.ejpain.2009.02.005.

[123] D.C. Spray, R. Rozental, M. Srinivas, (2002) Prospects for rational development of pharmacological gap junction channel blockers, Curr Drug Targets, 3 : 455-464 doi: 10.2174/1389450023347353.

[124] M. Hanani, E. Blum, S. Liu, L. Peng, S. Liang, (2014) Satellite glial cells in dorsal root ganglia are activated in streptozotocin-treated rodents, J Cell Mol Med, 18: 2367-2371 doi: 10.1111/jcmm. 12406.

[125] P. Woodham, P.N. Anderson, W. Nadim, M. Turmaine, (1989) Satellite cells surrounding axotomised rat dorsal root ganglion cells increase expression of a GFAPlike protein, Neurosci Lett, 98: 8-12 doi: 10.1016/0304-3940(89)90364-9.

[126] J.L. Stephenson, M.R. Byers, (1995) GFAP immunoreactivity in trigeminal ganglion satellite cells after tooth injury in rats, Exp Neurol, 131: 11-22 doi: 10.1016/0014-4886(95)90003-9. 
[127] N.J. Abbott, L. Ronnback, E. Hansson, (2006) Astrocyte-endothelial interactions at the blood-brain barrier, Nat Rev Neurosci, 7: 41-53 doi: $10.1038 / \mathrm{nrn} 1824$.

[128] P. Ballabh, A. Braun, M. Nedergaard, (2004) The blood-brain barrier: an overview: structure, regulation, and clinical implications, Neurobiol Dis, 16: 1-13 doi: 10.1016/j.nbd.2003.12.016.

[129] C. Giaume, L. Leybaert, C.C. Naus, J.C. Saez, (2013) Connexin and pannexin hemichannels in brain glial cells: properties, pharmacology, and roles, Front Pharmacol, 4: 88 doi: 10.3389/fphar.2013.00088.

[130] M. Theis, C. Giaume, (2012) Connexin-based intercellular communication and astrocyte heterogeneity, Brain Res, 1487: 88-98 doi: 10.1016/j.brainres.2012.06.045. [131] A.H. Cornell-Bell, S.M. Finkbeiner, M.S. Cooper, S.J. Smith, (1990) Glutamate induces calcium waves in cultured astrocytes: long-range glial signaling, Science, 247: 470-473 doi:

[132] A. Verkhratsky, J.J. Rodriguez, V. Parpura, (2012) Calcium signalling in astroglia, Mol Cell Endocrinol, 353: 45-56 doi: 10.1016/j.mce.2011.08.039.

[133] T. Li, X. Chen, C. Zhang, Y. Zhang, W. Yao, (2019) An update on reactive astrocytes in chronic pain, J Neuroinflammation, 16: 140 doi: 10.1186/s12974-0191524-2.

[134] A. Verkhratsky, M. Matteoli, V. Parpura, J.P. Mothet, R. Zorec, (2016) Astrocytes as secretory cells of the central nervous system: idiosyncrasies of vesicular secretion, EMBO J, 35: 239-257 doi: 10.15252/embj.201592705.

[135] L. Pellerin, P.J. Magistretti, (1994) Glutamate uptake into astrocytes stimulates aerobic glycolysis: a mechanism coupling neuronal activity to glucose utilization, Proc Natl Acad Sci U S A, 91: 10625-10629 doi:

[136] L. Pellerin, P.J. Magistretti, (2012) Sweet sixteen for ANLS, J Cereb Blood Flow Metab, 32: 1152-1166 doi: 10.1038/jcbfm.2011.149.

[137] P. Jakoby, E. Schmidt, I. Ruminot, R. Gutierrez, L.F. Barros, J.W. Deitmer, (2014) Higher transport and metabolism of glucose in astrocytes compared with neurons: a multiphoton study of hippocampal and cerebellar tissue slices, Cereb Cortex, 24: 222-231 doi: 10.1093/cercor/bhs309.

[138] A. Allen, C. Messier, (2013) Plastic changes in the astrocyte GLUT1 glucose transporter and beta-tubulin microtubule protein following voluntary exercise in mice, Behav Brain Res, 240: 95-102 doi: 10.1016/j.bbr.2012.11.025. 
[139] A.M. Brown, B.R. Ransom, (2007) Astrocyte glycogen and brain energy metabolism, Glia, 55: 1263-1271 doi: 10.1002/glia.20557.

[140] L.K. Bak, A.B. Walls, A. Schousboe, H.S. Waagepetersen, (2018) Astrocytic glycogen metabolism in the healthy and diseased brain, J Biol Chem, 293: 7108-7116 doi: 10.1074/jbc.R117.803239. 


\section{Figure legends}

Figure 1. Classification of neuroglia

Figure 2. Comparative physiology of astrocytes and satellite glial cells.

Astrocytes and SGCs are fundamentally homeostatic, supportive cells that maintain optimal environment within brain parenchyma or within peripheral ganglia, respectively. Astrocytes and SGC express homeostatic transporters such as excitatory amino-acid transporters $1 / 2$ (EAAT1/2), $\mathrm{Na}^{+}-\mathrm{K}^{+}$ATPase (NKA) and inward rectifier $\mathrm{K}^{+}$channels $\left(\mathrm{K}_{\mathrm{ir}} 4.1\right)$. In astrocytes these transporters are responsible for glutamate clearance and $\mathrm{K}^{+}$buffering, whether the same functions are executed by SGCs remains to be tested. Astrocytic endfeet form parenchymal part of blood brain barrier, known as glia limitans vascularis. The SGCs are close to intarganglionic blood vessels, but apparently do not form a tight barrier. Astrocytes and SGCs express numerous types of receptors. Astrocytes possess AMPA and NMDA glutamate receptors (AMPAR and NMDAR), $\mathrm{P}_{2} \mathrm{X}_{7}$ purinoceptors, nicotinic acetylcholine receptors (NAchR), metabotropic $\mathrm{P} 2 \mathrm{Y}$ purinoceptors, $\alpha / \beta$ adrenoceptors, cannabinoid receptors (CB1-R) and many others. Currently established receptor expression in SGCs is more limited, and most of the available information relates to metabotropic P2Y receptors and ionotropic P2X7 receptors. Astrocytes and SGCs also express the "maxi" channels pannexin1 (Panx1) and P2X7 receptors, in addition astrocytes possess connexin-assembled hemichannels (HC); all these molecules allow the release of signaling molecules such as ATP. Operation of these molecules underlies glial signaling functions. 


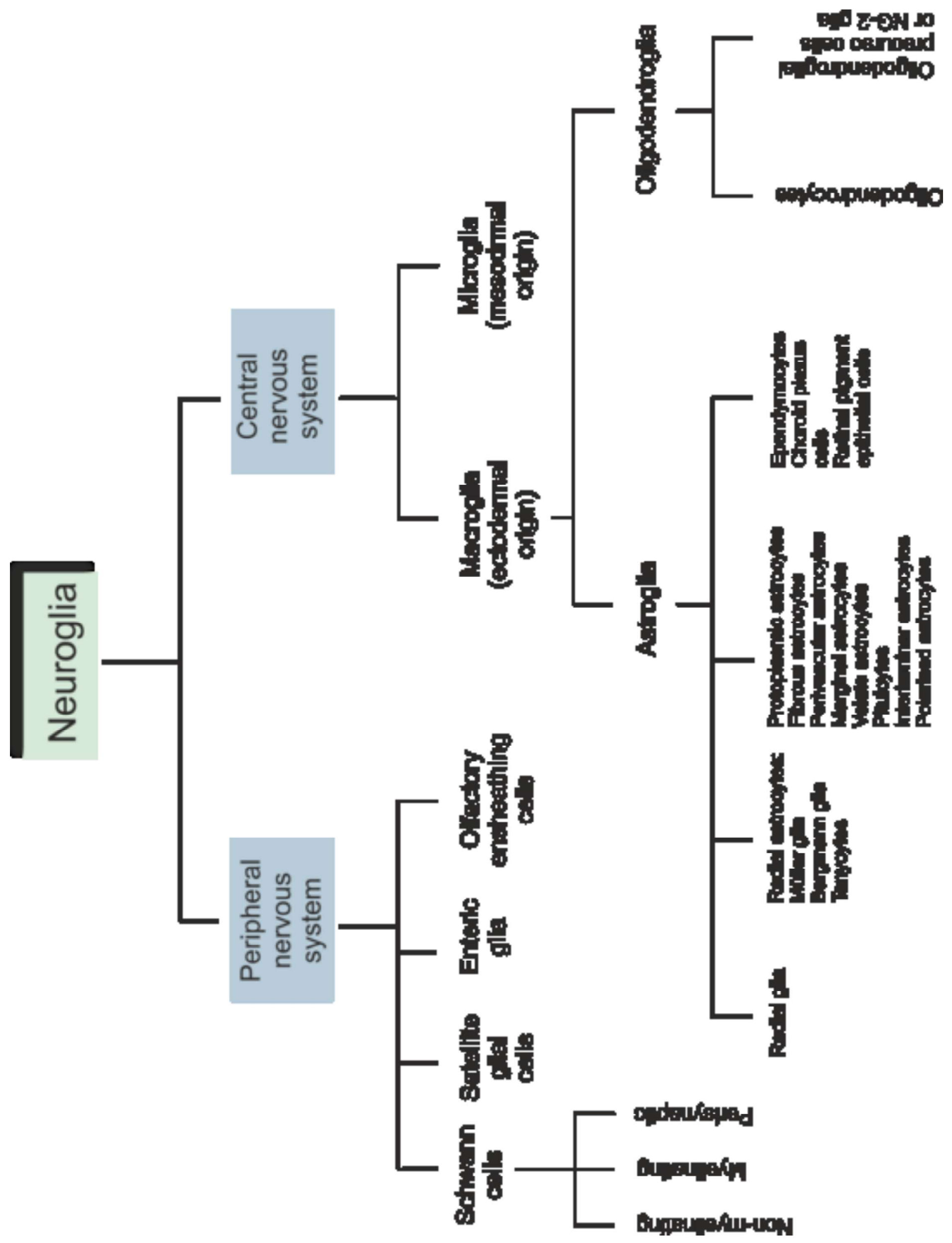



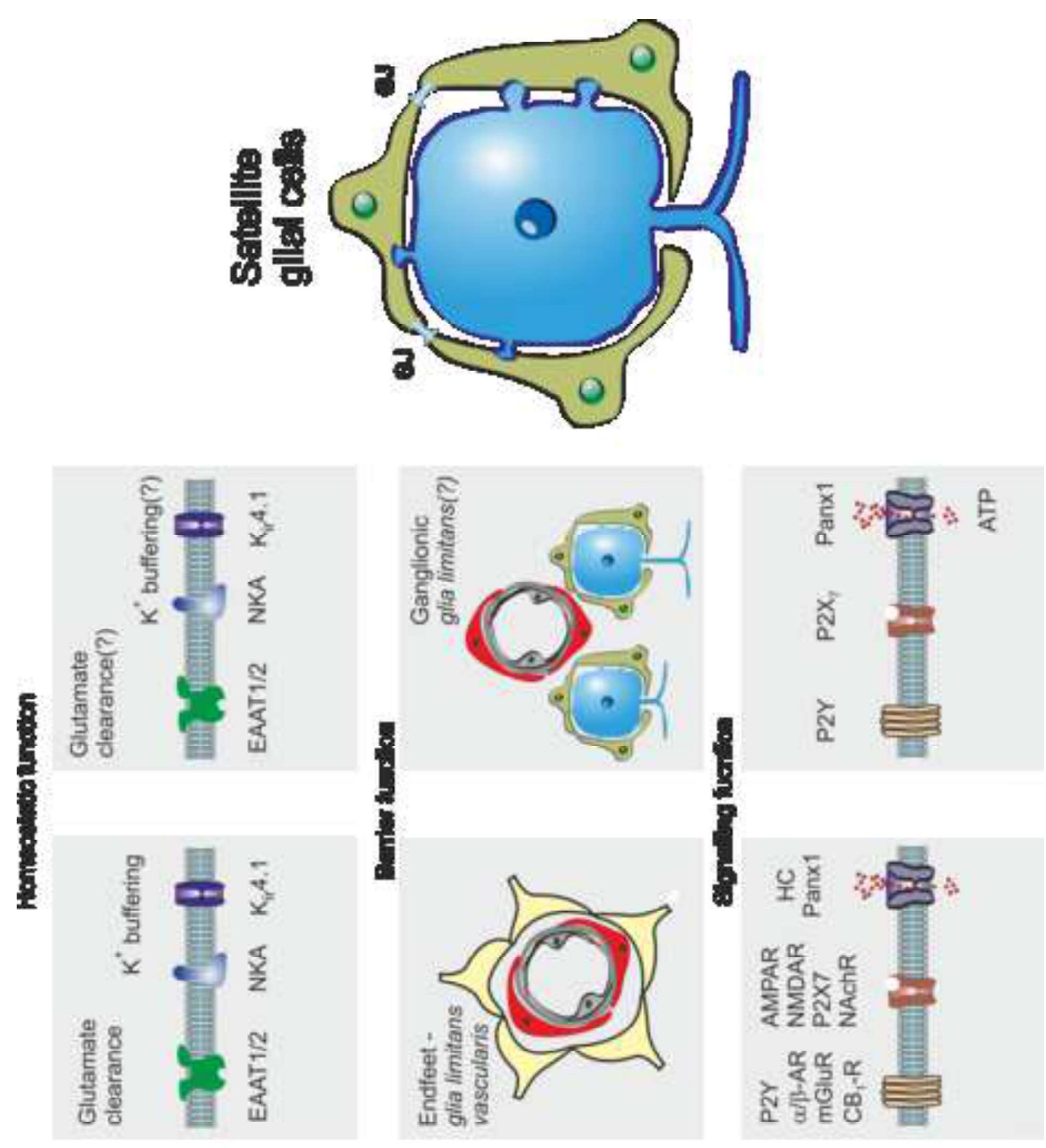

$N$
$\frac{0}{2}$
$\frac{\sigma}{4}$

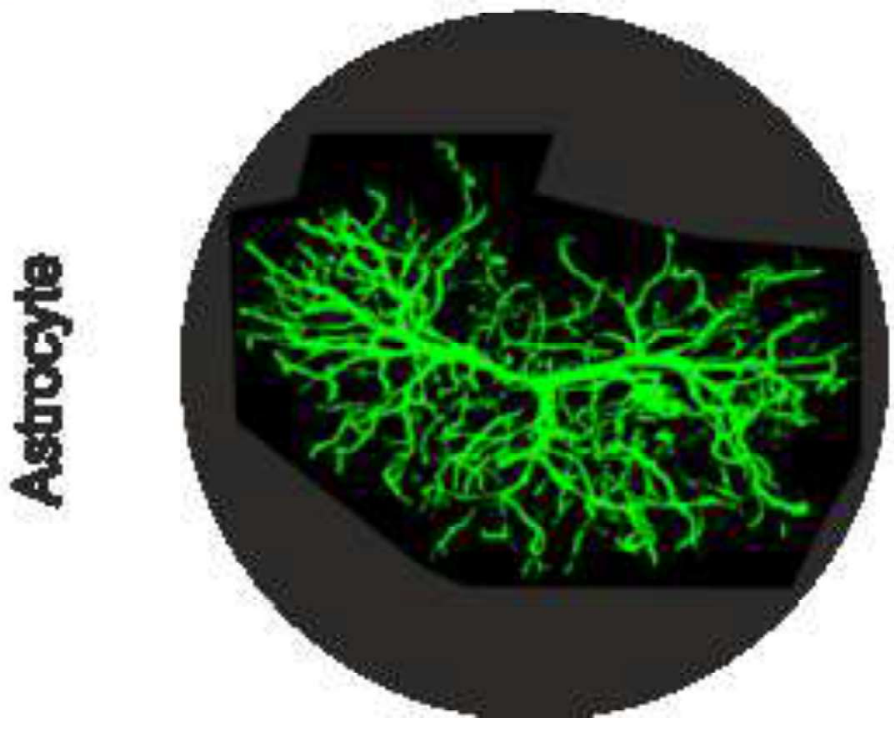




\section{Tables}

Table 1. Comparative physiology and pathophysiology of astrocytes and satellite glial cells

\begin{tabular}{|c|c|c|c|c|}
\hline Property & Astrocytes & References & $\begin{array}{l}\text { Satellite } \\
\text { glial ells }\end{array}$ & References \\
\hline Polarized structure & + & {$[6,14,16]$} & $\begin{array}{l}? /+ \\
\text { see text }\end{array}$ & \\
\hline $\begin{array}{l}\text { Forming functional } \\
\text { units with neurons }\end{array}$ & $\begin{array}{l}+ \\
\text { Can be present at } \\
\text { several levels (see } \\
\text { text) }\end{array}$ & & & {$[38,40]$} \\
\hline $\begin{array}{l}\text { Forming functional } \\
\text { units with non- } \\
\text { neuronal cells } \\
\text { including } \\
\text { vasculature }\end{array}$ & $\begin{array}{l}+ \\
\text { Astrocyte as a } \\
\text { central element of } \\
\text { neuro(glio)vascular } \\
\text { unit }\end{array}$ & {$[15,33]$} & + & \\
\hline Territorial domains & + & {$[6,14]$} & - & \\
\hline Role in BBB & + & {$[33,127,128]$} & - & \\
\hline $\begin{array}{l}\text { Control of blood } \\
\text { vessels }\end{array}$ & + & {$[34,35]$} & - & \\
\hline $\begin{array}{l}\text { Contacts with } \\
\text { blood vessels }\end{array}$ & + & {$[31]$} & $?$ & \\
\hline $\begin{array}{l}\text { Coupling by gap } \\
\text { junctions }\end{array}$ & $\begin{array}{l}+ \\
\text { Extensive, involves } \\
\mathrm{Cx} 43, \mathrm{Cx} 30 \text { and } \\
\mathrm{Cx} 26\end{array}$ & $\begin{array}{l}{[23,25,129,} \\
130]\end{array}$ & $\begin{array}{l}+ \\
\text { Limited, } \\
\text { involves } \\
\text { Cx43 and } \\
\text { Cx36 }\end{array}$ & $\begin{array}{l}{[55,56,} \\
114-117, \\
121]\end{array}$ \\
\hline Calcium waves & $\begin{array}{l}\text { Observed both in } \\
\text { culture and in the } \\
\text { intact tissue }\end{array}$ & {$[131,132]$} & $\begin{array}{l}\text { Observed } \\
\text { in culture; } \\
\text { not tested }\end{array}$ & {$[76,91]$} \\
\hline
\end{tabular}




\begin{tabular}{|c|c|c|c|c|}
\hline & & & $\begin{array}{l}\text { in the intact } \\
\text { tissue }\end{array}$ & \\
\hline $\begin{array}{l}\text { Microenvironment } \\
\text { control }\end{array}$ & Confirmed & [19] & $\begin{array}{l}\text { Postulated, } \\
\text { but not } \\
\text { tested. }\end{array}$ & [40] \\
\hline $\begin{array}{l}\text { Neurotransmitter } \\
\text { transporters }\end{array}$ & $\begin{array}{l}\text { + Function } \\
\text { observed }\end{array}$ & {$[19,21]$} & $\begin{array}{l}\text { Identified, } \\
\text { but } \\
\text { function } \\
\text { not tested. }\end{array}$ & {$[54,85]$} \\
\hline Phagocytosis & + & [57] & + & [38] \\
\hline $\begin{array}{l}\text { Antibody } \\
\text { presenting cell } \\
\text { function }\end{array}$ & + & {$[58,59]$} & + & \\
\hline $\begin{array}{l}\text { Reactive response } \\
\text { to peripheral injury }\end{array}$ & + & [133] & + & $\begin{array}{l}{[54,91,} \\
120,125, \\
126]\end{array}$ \\
\hline $\begin{array}{l}\text { Secretion of } \\
\text { neuroactive factors } \\
\text { including } \\
\text { neurotransmitters }\end{array}$ & + & [134] & + & {$[37,75]$} \\
\hline Receptors & + & [6] & + & $\begin{array}{l}{[66-68,71,} \\
73,77]\end{array}$ \\
\hline Subtypes & + & {$[6,47,48]$} & $\begin{array}{l}\text { Not } \\
\text { researched }\end{array}$ & \\
\hline $\begin{array}{l}\text { Metabolic support } \\
\text { of neurons }\end{array}$ & + & {$[135,136]$} & $?$ & \\
\hline $\mathrm{K}^{+}$buffering & + & {$[87,88]$} & $\begin{array}{l}\text { Postulated, } \\
\text { but not } \\
\text { tested. }\end{array}$ & \\
\hline Glucose transport & + & {$[137,138]$} & $?$ & \\
\hline Chemoreception & + & {$[94-96,99]$} & $?$ & \\
\hline
\end{tabular}




\begin{tabular}{|l|l|l|l|l|}
\hline $\begin{array}{l}\text { Presence of } \\
\text { glycogen }\end{array}$ & + & {$[139,140]$} & + & {$[38]$} \\
\hline $\begin{array}{l}\text { Mechanosensory } \\
\text { functions }\end{array}$ & $\begin{array}{l}\text { Astrocytes act as } \\
\text { central } \\
\text { chemosensors for } \\
\mathrm{pH}, \mathrm{CO}_{2}, \mathrm{Na}^{+} \text {and } \\
\mathrm{O}_{2}\end{array}$ & {$[92,93,100]$} & $?$ & \\
\hline
\end{tabular}

